\title{
Interpreting the Islamic Spiritual Dimension in an Educational Aspects
}

\author{
Abdullah Firdaus*, Fuad Rahman, M. Fadhil \\ Postgraduate School \\ Islamic State University of Sulthan Thaha Saifuddin \\ Jambi, Indonesia \\ *abd_firdaus70@yahoo.com
}

\begin{abstract}
The aspect of spirituality became an important point in religious behavior and simultaneously imaging a religious integrity. As a system of building spirituality of a human being, Sufism had related practically to what a System of Education sounds toward building a character. This research was determined to explore the mutual impact of a Sufism and education toward building the spirituality of a human; and his emotion-intellectual building. The main theory that related to Islam dynamism and education used the theory from Iqbal (1930) and the theory of spiritualism from Nicholson (2007). This study used a qualitative research with data collection techniques was literature review. The main source of data in this research was information, both in the form of manual text and digital text. Technique of Data analysis was content analysis approach. The results of this study indicated that Sufism and Education as a system of building ESQ of a human in its ideal essence did not only reflect the complete intimacy of a Muslim with his God through the assertion of Khudi but also it manifests the creativity and contribution of believers in the social aspect (bekhudi), which was based on religious values and the spirit of truth.
\end{abstract}

Keywords—spirituality, Sufism, education, khudi, bekhudi

\section{INTRODUCTION}

As a very well-known figure in the world of the Islamic modernist thought movement, as well as one of the founding figures of the Pakistani state, he is also known as a poet and philosopher. Iqbal had unique in the concept of education, the concept of Islamic spirituality which not only focused on conceptual spiritual development but also abstract spiritualism. Iqbal believes that religion should be a source of inspiration and power which should conquer the world. The scriptural texts always connect between logical reasoning, the natural phenomena, and the universe. Even the Quran is a book which emphasizes more on the aspects of attitude or action rather than the idea [1]. So the issue of action becomes very important to reflect an idea. In this context, the spiritual dimension will be meaningful if it is manifested in a social work frame. Iqbal also believes that Tawhid (the oneness of God) and The Messages of Prophet Muhammad are the source of Spiritual and Intellectual power due to gain a perfect personality (Khudi) and a social matter (Bekhudi) [2].
Iqbal was a well-known as a poet-philosopher rather than educator. Though he does not provide any definite educational technique or methodology but he did what was far more valuable and significant to those basic and principles of education. Therefore, we found Iqbal focused on individuality building. No one can develop any intelligent theory of education without consciously postulating some conception the nature of the individual and community. For the essence of the educative process had related to contact of an individual and his environment [3].

This means that the spiritual and social aspects of a person have an integral relationship to one another. In implementing this concept, Iqbal created the steps which are started from selfunderstanding (Khudi) and society (Bekhudi), which was conducted by sharpening the education or the intellectual power of the Muslims through the introduction of history and the experiences of the earliest Muslims. The meaning of Khudi was personal or individual impact and the meaning of bekhudi was social or community impact. This research was determined to explore the mutual impact of a Sufism and education toward building the spirituality of a human and his emotionintellectual building.

\section{METHODS}

The study is a qualitative research. The writers would describe the finding and explain it detail. Technique for collecting the data, the writer used library research. The researchers did extensive review of the related available literature, collected the data and information pertinent to the research. The researchers took data through internet, e-books, articles at journal, and some books at library. After that, the technique for analyzing the data, the writer used content analysis.

\section{RESULTS AND DISCUSSION}

The bitter experience that afflicted the Asian people from the oppression and injustice of the Western imperialists as well as those that afflicted Muslims are a crucial, non-negotiable issue to embark on the Muslims social and spiritual awakening. The development of progress in terms of independence in 
Muslims, for example in terms of politics, economy, education, and health. Then on the spiritual: the spiritual meaning exemplified by the friends. There must be the involvement of several parts, namely scholars, rulers, and Sufism experts. It's obviously seen that Iqbal perceives that the spiritual awakening was always in line with social reformation. There are three domains which became the focus of Iqbal to reform.

First, in religious and intellectual aspects, deviation happens on the aspect of the Aqedah (faith) which is disgraced by shirk (associate God). From the Sufism aspect, the spiritual dimension experience is more to describe an escape and helplessness. In addition, from an intellectual point of view, there is an intellectual stagnation in which Islamic thinkers are only transfixed and uncritically profess the Western materialistic thought without criticizing and evaluating the truth of those ideas. Such phenomena should be addressed by reconstructing the understanding of Islamic values and valid religious thought of philosophical and scientific approaches by considering the logical and empirical aspects which transpire in social realities of the society [4].

Therefore, according to Iqbal, material and spiritual aspect, science and spiritual, individual and community are important in connection between each other. In order to translate the ideal of Islam, that's why a strengthening the intellectual aspect must be in line with the awareness and appropriate religious understanding. In the other hand, Iqbal stressed the significance of action both in Sufism and education. The aim of education according to Iqbal is whom finally takes an active part in contribution of community building.

The modern societies have been preoccupied with their logical reasoning only. They ignored their soul's direction toward the perfect spiritual life which pervades depths into the heart. Thus, intellectually, they are confined in their personal conflicts, economically, and politically [4]. Therefore, the authentic progress of one society will only be achieved if they integrate the development of the intellectual aspect and education with revelation.

The second, in the social aspect, Iqbal considers that it is important for Muslims to reconstruct religious understanding for all aspects. In this context, Iqbal has the step of mentalspiritual revolution and social reformation in two points. First, self-empowerment theory or khudi, means the reinforcement of individual potential through good deeds knowledge. Second, the concept of bekhudi, means the efforts to translate the selfpotential productively into the public space [4].

The Third, in the political aspect, Iqbal expresses the idea of construct an independent and sovereign Muslim nationhood as well as Muslim who have a distinctive character based on Devine reality (The concept of Tawhid-Oneness of God, Allah Almighty) and Risalat (Belief in Finality of Prophet-hood, Prophet Muhammad) as it is implemented in Khudi and bikhudi theories.

Iqbal observes that the Islamic spiritual movement in Muslim community was influenced by such as a kind of mysticism which made Muslims ignored the reality and weakened and imprisoned them in a khurafat (animism and dynamism). Sufism has fallen from high prestige as the power of spiritual education to the exploitation of gullible ignorance. Due to the number of digression of the Islamic spiritual substance which supposed to be the strength for individual and Islamic community development, Iqbal criticized the practice of zuhud (asceticism) practiced by the Sufis lately which undermined the human potential. Indeed, as social creature, humans are required to keep progressing and developing, as well as exploring the universe. According to Iqbal, "the exaggerated zuhudism (asceticism) practiced by the Sufis today has deceived people into seeing the most important aspect of Islam as social politics" [1]. According to Iqbal, Education and Spirituality as perceived by Iqbal should involve the social environment, as it is as basis for straightening the Khudy. Therefore, the Sufism characteristic as described by Iqbal is more active in the social sphere. It is by making people's spiritual aspects to live and dynamically moving and to be progressive in actual life [5].

Iqbal views the implementation of spiritual values in public spaces is an obligation. Due to Sufism as a power in the spirituality of Islam. According to Iqbal, Sufism in its pure form has succeeded in establishing and directing the practice of religious teachings and values to Muslims. However, the practice of Sufism appearing today, completely ignores the modern thought (scientific progress) [1]. The deviation in Islamic tasawuf essentially undermines the Muslims and tarnish the teachings of Islam itself. According to Iqbal, "the ideal of a person's religion and morality does not lie in his mortal "(self-negation) but on his self-affirmation" [6].

According to Iqbal, Sufi tariqah which is followed by a large group of Muslims in the world has negatively affected the spirit of creativity that is driven by Islam. This Tasawuf style leads more to negative direction [7].

To dissolve the tangles occurring in understanding and translating the spiritual dimensions of Islam into the public sphere, Iqbal offers the concept and approach of Sufism that combines the clarity of the soul and the sharpness of mind in the guidance of revelation. Then it is perfected in the form of action and progress in the real world (social appear), between the heart and common sense, faith, and science will synergize in proportion. The integration of all these elements in the public sphere reflects the depth of the 'tafakur' implied by the Qur'an. This means "only through tremendous actions, a believer would attain an al-ittisal stage to God without losing his identity. So that, he is able to transcend the boundaries of space and time. The real action in its highest form is contemplation".

The power of Sufism lies in the clarity of mind, the strength of heart and soul that is proactively involved in establishing the real world. The implementation of tafakur and the struggle of values in order to find the ideal value for social life at one point is unneeded [8]. 
Therefore, Iqbal is among those who believe in al-baqa '. If there is a mysticism assuming that this realm is just an illusion and there is tasawuf which sees nature as a representation of the majesty, beauty and the will of God. So, Iqbal is with the mystic who believes in this second concept. Iqbal is with the Sufi scholars who declare 'yes' to this life and not those who declare 'no' to this life [4].

Iqbal rejects the meaning of Sufism which con notes the weakening of the spirit and creativity of one's thought. The practice of Sufism is more like a philosophy than the behavior of zuhud. Even Iqbal denounced the pairs who exploited their followers in the name of Sufism [9].

Through the theory of khudi which is intended as an effort to explore the direct depth of one's soul, is an alternative proposed by Iqbal in applying the substance of spirituality of Islam. He also resisted the negative influence of Hindu panthaism and Hellenistic Asceticism of Persia. This means 'the concept of self-empowerment in the perspective of khudi gives positive power that cross over the meaning of negativism (self-negation) arising in Islamic Sufism as a result of ancient Indian culture and other foreign spirituality influence' [4], [9]. It is obviously clear that Iqbal's educational philosophy meets his concept of spirituality in which both aim to build the individuality and the community

In connection to the issue of Sufism as narrated before, we find that Iqbal was seriously striving to restore the form of Sufism to its original type. It is a style of Sufism which encourages Muslims to authorize the world with the sharpwitted and the sincerity of soul. It is a Sufism which conveys progress by conquering the world and worldly interests; the progressive tasawuf which combines the spiritual power with social applications as practiced by The Prophet [8]

\section{CONCLUSION}

Sufism as a spiritual revolution Muslims should always be closed to God in order to form man plenary personalities who reach the intersection of the importance of integrating between the guidance of revelation with intellectual intelligence with spiritual maturity. Therefore, Tawhid was a basic to educate Muslim in understanding the divine reality. According to Iqbal the aim of education should be the understanding of divine reality (The concept of Tawhid: Oneness of God, Allah Almighty) and Risalat (belief in finality of Prophet-hood, Prophet Muhammad).
According to Iqbal that Sufism and education as an integral part of the establishing religion entirely. The practice and experience of Sufism in accordance with what was practiced by the Prophet and his Companions, ultimately will actually function effectively in forming man's personality. This spiritual aspect of Islam, in its pure form according to Iqbal was another dimension of the power and truth of Islam in bringing mankind to justice and universal prosperity. As well as the education sounds in it real ideal.

According to Iqbal, a social environment and community (bekhudi) was important for upgrading the individuality (Khudi). As a social being, a man should accelerate his social part due to his spiritual experience as well as his intellectual practice.

\section{ACKNOWLEDGMENT}

This research was conducted by involving various parties. Therefore, I would like to express my very great appreciation to all parties involved in this research for their valuable and constructive suggestions during the planning and development of this research work. Hopefully, this research could provide positive benefits and contributions to the development of education and science in the Islamic world for a more modern Islam in education.

\section{REFERENCES}

[1] M. Iqbal, The reconstruction of religious thought in Islam. Stanford University Press, 2013.

[2] R.A. Nicholson, Secret of The self (Asrar-i Khudi). Lahore: SH.Muhammad Ashraf. 1975

[3] K.G. Saiyidain, "Iqbal's Educational Philosophy," Dialogue Can. Philos. Assoc., vol. 3, no. 2, p. 284, 1936.

[4] B. CAzizi and M. Al-cArabi, Muhammad Iqbal Fikruhu al-Dini wa alFalsafi. Kaherah: Dar al-Kutub, 1999.

[5] M.S. Sheikh, Studies in Iqbal's Thought and Art: Select Articles from the Quarterly" Iqbal.". Bazm-i Iqbal, 1972.

[6] R.A. Nicholson, Mystics of Islam. London G.Belkk and sons Ltd. 1914.

[7] H. Malik, "Iqbal, Poet-Philosopher of Pakistan," 1971.

[8] S.A. Vahid, Thoughts and Reflections of Iqbal. Sh. Muhammad Ashraf, 1992.

[9] B. DR.H.H, Glimpses of Iqbal's Mind and Thought. Jakarta: Bulan Bintang, 1979. 